\title{
Economic sovereignty of a modern state in the context of sustainable development
}

\author{
Mykola Starinskyi*, Zhanna Zavalna**
}

Received: 2021-06-24

Accepted: 2021-08-01

DOI: http:/ / doi.org/ 10.46489/lbsh.2021-1-2-1

\begin{abstract}
The article deals with economic sovereignty as a part of national sovereignty. We found that researchers fail to pay adequate attention to the economic sovereignty of Ukraine in the context of stable development. We use the doctrine method of law research in order to answer four research questions. First, we study the establishment of sovereignty in the constitutions of some developing countries. Second, we investigate the notion and meaning of economic sovereignty in academic doctrine. Third, we describe and distinguish the peculiar features of economic sovereignty entrenchment using the example of some developed countries. Fourth, we name the exact problems of the realisation of the economic sovereignty of Ukraine. For each of these issues, we provide specific recommendations concerning the ensuring of stable development of Ukraine for the latter to be able to join the EU. Within the framework of the discussion, we give recommendations for taking into consideration the political and other mutual influences of other countries upon the economic sovereignty of Ukraine. The recommendations provided can be used to develop suggestions concerning stable development strategies.
\end{abstract}

Keywords: economic sovereignty, economic functions of the state, fair partnership, interstate interaction, legal harmonisation

\footnotetext{
* Mykola Starinskyi, Doctor of Law, Professor, Professor of Department of Administrative, Economic Law and Financial and Economic Security, Academic and Research Institute of Law, Sumy State University,

Rimskogo-Khorsakova str., 2, 40000 Sumy, Ukraine, ORCID: https://orcid.org/0000-0003-2661-5639

** Zhanna Zavalna, Doctor of Law, Professor, Professor of the Department of Civil Law, V.N. Karazin Kharkiv National University, Svobody sq.,4, 61022 Kharkiv, Ukraine, e-mail: zavaln@karazin.ua (corresponding author), ORCID: https://orcid.org/0000-0001-6511-2482
} 


\section{INTRODUCTION}

Our humankind nowadays is on a top step in its development which manifests itself in both scientific achievements and the living standard of its representatives. At the same time, we have to pay for this with a highly significant influence on the environment, both natural and social, and with profound exhaustion of our natural resources. Considering that we all live on one planet, the developed countries tend to violate the interests of other countries quite often when pursuing their interests. As a result, today, knowledge is coming to the foreground. While meeting the needs of the modern civilization, it allows ensuring its stable and peaceful existence in the future and the protection of the generations to come.

One of the most critical factors of stable development in the modern world is globalization as the process of economic, political and cultural integration and unification in the world (Montanaro \& Violi, 2020). Influenced by it, the world economic system is turning into a complex of the economic systems of individual countries that interact actively. However, the absolute priority given to the market and free competition has caused the denial of the role of a national state as an efficient economic regulator. Consequently, states tend to fulfil more of their functions in cooperation with other states, and for that purpose, they withdraw their resources to meet everyday needs. The processes mentioned above are on full display in the functioning of the developing countries since the economically developed ones try to influence their development by pursuing their interests and priorities and at the same time substituting them with common interests. This situation results in the imbalance and obstacles on the way of developing countries' fair partnership and development. In this context, as it seems, any further development can be ensured only on the principles of respect, global partnership and cooperation among all countries of the world, thus allowing meeting all the objectives of stable development. Therefore, in our opinion, it is reasonable at the global and interstate level to provide the realization of one of the essential functions for the modern stable development of a state, i.e. the economic one, which is materialised in the economic sovereignty.

\subsection{Literature Review}

Research of a state's economic sovereignty is quite a complicated task because it requires taking into account both the sovereignty in general and a part of it, i.e. economic sovereignty. The analysis of modern research literature shows no unified definition of the notion of "state". In the article, we use a narrow definition of the state that includes a feature of sovereignty too, which traditionally is perceived as supremacy within one's borders, independence and self-sufficiency in domestic and external affairs. At the same time, modern researchers treat sovereignty as a variable phenomenon that fascinates and disturbs its diversity (Ruggie, 1998) and polysynthetism of the notion (Stankiewicz, 1969). Before J. Bodin, it was interpreted as a "secondary contextdependent predicate" (Walther, 1976), which could also have no political meaning.

At the current stage of social development in the context of the sovereignty value being confirmed (Duke, 2019), the ideas about the "vertical dispersion of sovereignty" are expressed (Pogge, 1992) because our world has entered the post-sovereignty era (Cormick, 2010). Numerous concepts are being invented with the view of explaining the current condition of sovereignty in the time of the new global order, in particular, "post-Westfalian sovereignty" (Lapid, 2001), “divisible sovereignty" (Witte, 1998), "multilevel sovereignty" (Loughlin, 2006), "disintegrated sovereignty" (Slaughter, 2004). Furthermore, analyzing the economic situation in specific countries, some authors define many different types of sovereignty. These factors, in nature, do not ensure absolute power for the legitimate government on the territory of the country and present it as "graduated sovereignty" (Park, 2005; Holden, 2017) or "fragmented sovereignty" (Su, 2018) et cetera.

Considering the peculiarities of modern economic development of individual countries or regions, the authors investigate the role and place of sovereignty in certain branches of the national economy and differentiate digital sovereignty (Komaitis, 2021), energy sovereignty (Schelly et al., 2020; Abraham- 
Dukuma, 2020), and foodstuff sovereignty (Tilzey, 2017; Thompson, 2019; Laforge et al., 2021). Nowadays, the latter seems to be the most talked-about type of sovereignty in all modern research discussions.

With the escalation of old conflicts and emerging of new ones in different regions, the desire of the countries to protect their economic interests with various methods is only getting stronger. It is suggested that for this purpose, both internal democratic resources (use of civil society institutions to resolve conflicts based on the suppression of "seed sovereignty" (Hernández, et al., 2020), and international means (withdrawal from international treaties (Richardson \& Stähler, 2019) should be applied.

\subsection{The theoretical and legal background of the economic state sovereignty}

The sovereignty idea has long-lasting development in the works of J. Bodin, T. Hobbs, J. Locke, J.J. Rousseau, Hugo Grotius and lots of modern and contemporary philosophers. However, we believe that at the current stage of global economic development, the traditional perception of sovereignty must be revised, taking into account the Decisionism doctrine of Schmitt (1979) that claims: the one that makes decisions about the emergency is the sovereign (Schmitt, 1979).

Consequently, a state can be considered sovereign if it is absolutely independent in its territory, implements its development strategy, and uses all available resources. In other words, a state is sovereign if it develops and executes its development strategy regardless of the position of other states but at the same time observes the principle of state equality and noninterference in the domestic affairs of other countries.

In this article, we address the following research questions:

$\mathrm{RQ}_{1}$ : What are the features of the establishment of sovereignty in the constitutions of some developing countries?

$\mathrm{RQ}_{2}$ : What is the meaning of economic sovereignty in academic doctrine?

$\mathrm{RQ}_{3}$ : What features of the achievement of economic sovereignty entrenchment exist in developed countries?
$\mathrm{RQ}_{4}$ : What are the exact problems of the realization of the economic sovereignty in Ukraine?

\section{METHODS}

We conducted the research using the doctrine method of law research. To answer the research questions, we have studied the establishment and realisation of formal and actual sovereignty considering constitutional law-making instruments of several developed countries (US, Germany, France, Italy, Japan).

We analysed the Ukrainian foundation documents in their connection with the economic sovereignty of Ukraine. During analysis, we considered such traditional criteria for the developed countries as the founding rights of a nation, the right to natural resources, and the right to interstate interaction in the economy. Furthermore, we performed a qualitative analysis of the Constitution of Ukraine has to find the provisions that concern the establishment and realisation of economic sovereignty. We also discussed the possibility of clarifying the peculiarities of economic sovereignty that are crucial to reaching stable development.

This research follows the system approach. We understand economic sovereignty as a system of elements connected with the domestic and foreign policies of the states.

At the current stage of social development, the idea is dominant that a state is either founded by its population or "re-built" by it due to revolutions, liberation wars, and reforms. Thus, the nation itself is the source and the initial carrier of power and state sovereignty. The nation executes its sovereign power during elections, referendums, et cetera, and creates a state apparatus (governmental authorities), who it is then subordinate.

\section{RESULTS}

\subsection{Establishment of state sovereignty}

All constitutions we analyzed has specific provisions that establish the sovereignty, independence, and self-sufficiency of the given state. At the same time, certain remarks are worth mentioning as crucial for our research. First, a state establishes the order and procedure of fulfilling the government power and subordinates to it by distinguishing the 
notions of sovereignty and anarchy. Second, the execution of external functions by the state is objectified, among others, in the conclusion of international treaties, participation in international organizations, et cetera. This all results in the sovereignty limitation rising from the state's obligations to other parties. The states have created an interstate system of justice, within which the settlement of specific interstate issues is delegated to the non-state level.

So, we can divide state sovereignty into formal and actual. A state is formally sovereign if it is independent on its territory and executes its development strategy. The formally sovereign state uses all the available resources regardless of the position of other states and at the same time sticks to the principle of equality and non-interference. Actual sovereignty we understood as an attempt of a political organization of population on some territory to claim its supremacy, independence and selfsufficiency in domestic and international affairs. Such a claim to sovereignty must be constantly confirmed by reliable power controlling the territory and supported by the community.

As the analysis of current international relations shows, the most efficient way to support stats claim to actual sovereignty is to use all possible means to interfere in domestic affairs of other countries, impose one's will on them, i.e. oppress their claims to sovereignty. The states that constantly influence other countries' policies cultivate their dependence and create interstate coalitions around them. The states that manage to impose their will on others and demonstrate their superiority are called superpowers. Nowadays, there are two primary components of interstate superiority, namely military and economic. Before establishing the current world order, military superiority was enough. However, during the last century, civilization's development makes it insufficient. Thus, today actual sovereignty is a combination of military and economic superiority. Moreover, the economic component moving to the forefront and gets objectified in the economic sovereignty of the state.

\subsection{The notion and characteristic of economic sovereignty}

The economic sovereignty of any state is a kind of objectification of the substantial component in its actual sovereignty (Blishchenko, \& Doria, 2000). In literature, such notions as "finance sovereignty", "tax sovereignty", or "resource sovereignty" are also widespread, though with certain restrictions, along with "economic sovereignty" (Blishchenko, \& Doria, 2000; Mochernyj, 2005). In general, we can agree with such an approach since, in the context of globalization, a state possesses the economic possibilities to use its material resources independently, which are objectified in its finance, taxes, and currency earnings, allow it to be called economically sovereign.

The research literature on economic sovereignty contains different opinions concerning this institution (Blishchenko, \& Doria, 2000; Karro \& Zhyuar, 2002; Farhutdinov, 2008;). At the same time, we believe that Baidin (2010) best defined the notion of economic sovereignty, considered the elements of economic sovereignty to include the following: a) the right to join international associations; d) equality in international economic relations, respect for the economic interests of other countries, right to participate in the solution of international economic problems, first of all, those that concern the national interests. Understanding all these aspects let Baidin (2010) disclose the meaning of economic sovereignty and define it as a possibility for the state to make decisions regarding the development of its national economy by executing several sovereign rights of the state in economic areas. The mentioned sovereign rights in the economic area are objectified in the economic policy of the state.

The UN General Assembly adopted the Charter of Economic Rights and Duties of States (UN, 1974), taking into account that the economic sovereignty of a state means its ability to dispose of its resources independently from other countries. At the international level, this document established the main principles of international economic interaction among different states. In particular, these political and economic interaction principles include sovereignty, political independence, sovereign 
equality of all states, mutual and fair benefit, peaceful settlement of unfairness caused by the use of force that deprives any nation of the natural resources necessary for its normal development.

The Charter establishes the fundamental principle that declares the following: each state must possess unrestricted and absolute constant sovereignty upon all its natural resources, wealth and economic activity, including the right to possess, use and exploit. Furthermore, all states possess the right to dispose of their resources freely and act according to the established law and order objectified in three primary rights: to regulate and control foreign investments; regulate and control transnational corporations; nationalize, expropriate or transfer foreign property. Moreover, all states get the right to participate in international trade and other types of economic cooperation regardless of any differences in their political, social or economic systems. Finally, the Charter establishes that no state shall suffer discrimination based on such differences only.

By fixing these provisions at the international level, the UN intended to establish general principles of international economic interaction and create a fair international justice system. This requirement sets an obligation to all states on confirming specific provisions at national levels. In most states, the mentioned provisions are entrenched at the level of their constitutions.

The analysis of constitutional provisions shows that almost every constitution includes some provisions that establish the right of people to possess natural resources and be able to use them for the benefit of the nation. For example, Article 15 of the Constitution of Germany states that "the land and mineral wealth, natural resources and means of production can be transferred to common property or other types of the public economy according to the law..." (Maklakov, 2010). Constitutions of different states also contain some provisions that concern the financial element of their functioning, namely the provisions that determine the right of the state to establish the system of taxes and charges. In some cases, a state has the exclusive right to pass such laws (Article 105 of the Constitution of Germany). In others, it is ensured that only laws can introduce or cancel them; certain taxes and charges (Article 47 of the Constitution of the French Republic, Article 84 of the Constitution of Japan, section 8 Article 1 of the Constitution of the USA). (Maklakov, 2010; Shapoval, 2018).

The constitutions of different states also include some provisions that establish the sovereign right of the state to enter international relations with other states and conclude international treaties. In some cases, it means general civil cooperation (Article 88 of the Constitution of the French Republic) (Shapoval, 2018). In others, it concerns the right of governmental authorities to conclude agreements that are connected with international trade (section 8 Article 1 of the Constitutions of the USA) (Maklakov, 2010).

The constitutions pay much attention to the defence of countries' territory. In particular, they establish the right of the nation to the defence that the government executes (Article 20 of the Constitution of the French Republic, article 15-a of the Constitution of Germany) and the right to declare war to protect the state (Article 35 of the Constitution of the French Republic) (Shapoval, 2018; Maklakov, 2010).

The constitutions of some states also include interesting provisions if, for various social and political reasons, these states refuse war as a tool to settle international issues. For instance, Article 9 of the Constitution of Japan states the following: "Aspiring sincerely to an international peace based on justice and order, the Japanese people forever renounce war as a sovereign right of the nation and the threat or use of force as means of settling international disputes. In order to accomplish this aim, land, sea, and air forces, as well as another war potential, will never be maintained. Furthermore, the right of belligerency of the state will not be recognized" (Maklakov, 2010).

Thus, as we see, the primary trend of establishing economic sovereignty in constitutions manifests in:

- the fixation of the right of ownership of natural resources that can be found on the territory of states;

- its sovereign right to define and levy taxes, charges and customs duties from different types of economic activity carried out on the territory of the state; 
- the right to conclude international treaties and the right to defend its territory.

\subsection{Constitutional entrenchment of the economic sovereignty of Ukraine}

The economic sovereignty of Ukraine is deeply and widely entrenched by the legislative instruments that proclaimed its status as an independent state (Verkhovna Rada URSR, 1990-a; Verkhovna Rada URSR, 1990-b; Verkhovna Rada Ukrayiny, 1991-a; Verkhovna Rada Ukrayiny, 1991-b). When the Ukrainian parliament (the Verkhovna Rada) proclaimed the independence of Ukraine in the Declaration of State Sovereignty of Ukraine (1990), the criteria of sovereignty, among others, included economic independence, territory supremacy, internal and external security (Verkhovna Rada URSR, 1990-a). Considering the importance of economic development for an independent state, the Law of Ukraine "On Economic SelfReliance of the Ukrainian Soviet Socialist Republic" (1990) provided the basics of the sovereign economic rights of Ukraine enforcement. Particularly it emphasised the crucial role of economic self-reliance to secure the state sovereignty of Ukraine (Verkhovna Rada URSR, 1990-b). Thus, Ukraine selfdetermines economic status, the strategy of social and economic development and foreign policy independently.

The Constitution of Ukraine (adopted on June 28, 1996) expressed the development of listed provisions. It establishes the primary sovereign economic rights of the state (Verkhovna Rada Ukrayiny, 1996). For instance, Article 13 of the Constitution of Ukraine (1996) entrenches the juridical model of the ownership of land and other natural resources belonging to the people of Ukraine. The Constitution of Ukraine declares that the environment objects within the territory of Ukraine, its continental shelf and exclusive maritime (economic) zone are the objects of property rights of the Ukrainian people that is an independent holder of the property right of the specified objects (Verkhovna Rada Ukrayiny, 1996). The Ukrainian people shall have the right to utilise the natural objects of the people's property rights following the law. State authorities and local self-government bodies shall exercise the ownership rights on behalf of the Ukrainian people within limits determined by the Constitution. It should be highlighted that the Constitution of Ukraine provides the juridical objectification of the natural right to natural resources as a legal right of the Ukrainian people and binds the state to protect the land and other natural resources as the national wealth.

The Constitution of Ukraine declares the land to be the main item of national wealth that can be widely interpreted as everything that a nation owns in whatever way. In other words, national wealth includes material values and all natural resources, climate, works of art, et cetera (Tatsii, \& en al. (Eds.) 2011). Moreover, considering the high role of agrarian resources in the Ukrainian economy, the land is its main, basic and irreplaceable means of production that, along with the climate, human labour, and other production means, can ensure stable economic development of Ukraine both for its domestic well-being and in EU integration perspective.

Speaking about the sovereign right of Ukraine to control its financial system, it is worth studying paragraph 1 of part 2 of Article 92 of the Constitution of Ukraine (1996), according to which the following matters shall be determined exclusively by laws of Ukraine: the State Budget of Ukraine and the budgetary system of Ukraine; the system of taxation, taxes and levies; the principles of the formation and operation of financial, monetary, credit, and investment markets; the status of the national currency and the status of foreign currencies on the territory of Ukraine; a procedure for the formation and settlement of state domestic and foreign debt; and a procedure for the issue and circulation of state securities and their types and forms (Verkhovna Rada Ukrayiny, 1996).

According to Article 17 of the Constitution of Ukraine, protecting the sovereignty and territorial integrity of Ukraine, ensuring its economic and information security shall be the most essential function of the State and a matter of concern for all the Ukrainian people (Verkhovna Rada Ukrayiny, 1996). The defence of Ukraine and protection of its sovereignty, territorial integrity and inviolability shall be entrusted to the Armed Forces of Ukraine. Ensuring the security of the State and protecting the State borders of Ukraine shall be 
entrusted to respective military formations and law enforcement bodies of the State, whose organisation and operational procedure shall be determined by law.

The constitutional provisions that entrench economic sovereignty are developed in the legislative instruments that specify the constitutional norms and establish their execution procedure which proves the theoretical entrenchment of the economic rights of the state but also a possibility of their accurate fulfilment. Therefore, the analysis of the provisions included in the Constitution of Ukraine allows declaring that Ukraine as a state possesses adequate constitutional provisions that prove that its economic sovereignty is entrenched in the Constitution and can be supported according to the existing international system of justice.

\section{DISCUSSION}

In the latest decades of development in the modern world, the perception of the economic sovereignty of a state has changed significantly, especially if we consider the deepening integration processes. The expansion of free trade zones, states coming together in various unions and associations, and international financial and credit institutions' functioning greatly influenced this process.

The research shows that the activity of plenty of international organizations is based on the use of universal rules and norms of economic regulation that leads to the unification of national economic policies and fewer possibilities to take into consideration national economic interests (Melnyk, 2015; Gurrea-Martínez, 2019; Shadikhodjaev, 2021; Bronckers, \& Gruni, 2021). Especially it concerns the demand to harmonize national legislation with the regulations of the World Trade Organization that is a compulsory requirement for states that aspire to join this organization. The WTO bases on the principles of trade liberalization. It is the most favoured nation basis and the national regime that often contradict the differentiated national rules of internal market protection and taxation that make narrower the possibilities of national governments in the area of regulating the development of economy, especially in the countries with the economy in transition. A vivid example of the situation that proves the influence of the WTO upon economic sovereignty is the situation with Ukraine that met the demand to weaken the customs protection of its internal market while preparing itself to join the WTO and implemented the critically low levels of agriculture support.

The wide-known global financial organization - International Monetary Fund based on interference in sovereign economic rights. The analysis of the statutory documents of the International Monetary Fund shows that the provisions of the IMF Agreement regulate not only the functioning peculiarities of the fund itself but are also the source of legal regulation of financial relations on the territory of the member state (Starynskyi, 2015). The IMF activity intervents the economic sovereignty of the member states since it interferes with national governments' domestic policy. Fund's requirements concern the rates of monetary and tax policies and the directions of economic reforms, namely the increase of tariffs and prices.

The analysis of international economic interaction also proves that economic sovereignty suffers significantly because of international treaties' international restrictions. For instance, the Kyoto Protocol concluded in 1997 by a hundred countries demands that the developed countries, which account for $55 \%$ of carbon dioxide being discharged in the atmosphere of the Earth, should curtail harmful production (UN, 1997).

The transformation of approaches towards economic sovereignty perception and its contents has been greatly influenced by the position of some superpowers that do not separate economy and geopolitics under current conditions (Leonard, M. et al., 2019; Vidigal, 2020; Shaffer, \& Gao, 2020). For example, modern processes that are taking place in the world and connected with the launch of the Nord Stream 2 demonstrate that certain states with world monopolist status do not mind using blackmail to reach their political goals. It is also worth mentioning that some states take advantage of the poor financial condition of developing countries and grant them credits under such terms that can significantly influence their economy and foreign policy (Gelpern, 2021). 
Economic sovereignty is also influenced by the creation of special economic zones that provide preferences for certain states and regions and beget disproportions in the economic development of other states (Simo, 2020; Delimatsis, 2021). Such actions cause fragmentation of the legal framework in these countries and create the outlines for the unilateral transition under the jurisdiction of a special economic zone. Then regional economic regulation gets concentrated and influences the economic sovereignty of neighbouring states (Chi, 2021).

The above-mentioned theoretical structures of economic sovereignty were disrupted by the intense development of the financial sector and its fusing with cyberspace that has significantly weakened the ability of states to control their financial assets (Leonard, 2016; Paul T., (2019; Veerpalu, en al 2020; Lupo-Pasini, 2021). Some research and experts point at the possibility of the significant influence of cryptocurrencies upon the economy of states and the appearance of financial obligations (Evariest, 2020) though they offer specific perspectives of their regulation (Nabilou, 2019; Zetzsche, D., et al., 2021).

Nowadays, the described problems are waiting for solutions, forcing the global community to find them. Economic sovereignty issues move to the global level because economic sovereignty is a standard feature of any state and guarantees its existence as an independent and self-reliant player in foreign relations.

The academic importance and novelty of the research consist in the fact that the results received by the authors complete the existing knowledge about the peculiarities and problems of economic sovereignty realization in Ukraine and the world. Obtained results can be helpful to governments in making their strategies of economic development and strengthening international partnerships for more effective interstate cooperation.

\section{Limitations}

In our research, we focused on the existence of economic sovereignty and illustrated its entrenchment both in international regulations and at the level of constitutions in different states. At the same time, since the discussion about economic sovereignty realization under the novel conditions has just begun, the characteristic of any reasonable attempt to exercise economic sovereignty and its mechanisms remain unaddressed.

\section{CONCLUSION}

At the current stage, economic sovereignty and its realisation remain pressing because their solution allows independent states to become economically self-sufficient players in interstate relations.

The existing international system of justice acknowledges that states possess their economic sovereignty that is objectified in the following claims: a) to dispose of their resources; b) to determine their economic policy independently; c) to join international associations; d) to acknowledge the equality of all states in international economic relations; e) to respect national economic interests of states.

Almost all countries of the world establish their economic sovereignty in their constitutions and reserve their right to protect it with various means, including force. However, constitutions of some states do not acknowledge the right to war, especially to protect their economic sovereignty.

In Ukraine, economic sovereignty is established in the norms that determining the legal status of land, subsoil and other natural resources; regulating the procedure to determine financial and monetary policies; setting taxes and levies; providing grounds for protecting and defending Ukrainian territory.

The described norms serve as the fundamentals for the efficient use of the resources available in Ukraine as provide for the legal base to ensure its economic sovereignty. They can also be used as the legal base for economic development and the strengthening of international partnerships.

At the same time, the modern global development of our civilisation proves there are new challenges for the functioning of states themselves and for confirming their economic sovereignty, which requires extra attention when designing new mechanisms of its realisation. 


\section{References}

Abraham-Dukuma, M. (2020) Sovereignty, trade, and legislation: The evolution of energy law in a changing climate. Energy Research \& Social Science, 59, 101305. https://doi.org/10.1016/j.erss.2019.101305

Baidin, Yu.V. (2010). Ekonomichnyi suverenitet derzhavy: problemy vyznachennia zmistu. Deklaratsiia pro derzhavnyi suverenitet Ukrainy - peredmova yii nezalezhnosti ta demokratychnoho rozvytku. NDI derzhavnoho budivnytstva ta mistsevoho samovriaduvannia, 100-101.

Blishchenko, I.P. \& Doria, Z.H. (2000). Ponyatie ekonomicheskogo suvereniteta gosudarstva. Pravovedenie, 1, 200-217.

Bronckers, M. \& Gruni, G. (2021). Retooling the Sustainability Standards in EU Free Trade Agreements. Journal of International Economic Law, 24(1), 25-51. https://doi.org/10.1093/jiel/igab007

Chi, M. (2021). Regulation of Special Economic Zones Through Regional Trade Agreements: Confronting the Synergy Issue. Journal of International Economic Law, 24(2), 423442. https://doi.org/10.1093/jiel/igab016

Cormick, Mac N. (2010). Sovereignty and After. In H. Kalmo \& Q. Skinner (Eds.), Sovereignty in Fragments: The Past, Present and Future of a Contested Concept (pp. 151-68). Cambridge University Press.

Delimatsis, P. (2021). Financial Services Trade in Special Economic Zones. Journal of International Economic Law, 24, 277-297. https://doi.org/10.1093/iiel/igab023

Duke, G. (2019). Sovereignty and the common good. International Journal of Constitutional Law, 17 (1), 66-88. https://doi.org/10.1093/icon/moz005

Evariest, C. (2020). Financial Instruments Entail Liabilities: Ether, Bitcoin, and Litecoin Do Not. European Banking Institute Working Paper Series, 66. https://ssrn.com/abstract $=3630895$

Farhutdinov, I.Z. (2008). Ekonomicheskii suverenitet gosudarstva $\mathrm{v}$ usloviyah globalizacii. Pravo $i \quad$ bezopasnost', 3 . http://dpr.ru/pravo/pravo 24 12.htm

Gelpern, A., Horn, S., Morris, S., Parks, B., \& Trebesch, C. (2021). How China Lends: A Rare Look into 100 Debt Contracts with Foreign
Governments. Peterson Institute for International Economics, Kiel Institute for the World Economy, Center for Global Development, and AidData at William \& Mary. https://www.ifwkiel.de/fileadmin/Dateiverwaltung/IfWPublications/ifw/Journal Article/2021/How China_Lends. pdf

Gurrea-Martínez, A. (2019). The Dark Side of Implementing Basel Capital Requirements: Theory, Evidence, and Policy. Journal of International Economic Law, 22 (1), 125-152. https://doi.org/10.1093/jiel/igz002;

Hernández, C., Perales, H. \& Jaffee, D. (2020). Without Food there is No Resistance: The impact of the Zapatista conflict on agrobiodiversity and seed sovereignty in Chiapas, Mexico. Geoforum. https://doi.org/10.1016/i.geoforum.2020.08.0 $\underline{16}$

Holden, C. (2017). Graduated sovereignty and global governance gaps: Special economic zones and the illicit trade in tobacco products. Political Geography, 59, 72-81. https://doi.org/10.1016/i.polgeo.2017.03.002

Karro, D. \& ZHyuar, P. (2002). Mez̧dunarodnoe ekonomicheskoe pravo. Mezhdunarodnye otnosheniya.

Komaitis, K. (2021). Europe's ambition for digital sovereignty must not undermine the Internet's values. Computer Fraud \& Security.1, 11-13. $\quad$ https://doi.org/10.1016/S1361$\underline{3723(21) 00008-7}$

Laforge, J. M.L., Dale, B., Levkoe, C. Z. \& Ahmed, F. (2021).The future of agroecology in Canada: Embracing the politics of food sovereignty. Journal of Rural Studies, 81, 194-202. https://doi.org/10.1016/j.jrurstud.2020.10.025

Lapid, Y. (2001). Rethinking the 'International'. In A. Mathias, D. Jacobson \& Y. Lapid (Eds.), Identities, Borders, Orders: Rethinking International Relations Theory (p. 156-187). University of Minnesota Press.

Leonard, M. (ed.) (2016) Connectivity wars: Why migration, finance and trade are the geo-economic battlegrounds of the future. European Council on Foreign Relations. https://ecfr.eu/wpcontent/uploads/Connectivity Wars.pdf 
Leonard, M., Pisani-Ferry, J., Ribakova, E., Shapiro, J. \& Wolff, G. B. (2019). Redefining Europe's economic sovereignty. Bruegel Policy Contribution, 9. https://www.bruegel.org/2019/06/redefiningeuropes-economic-sovereignty/.

Loughlin, M. (2006) Ten Tenets of Sovereignty. In Neil Walker (Ed.), Sovereignty in Transition (p. 70). Bloomsbury.

Lupo-Pasini, F. (2021) Hidden sovereign finance. Capital Markets Law Journal, 16 (2), 165186, https://doi.org/10.1093/cmlj/kmab002

Maklakov, V.V. (red.) (2010). Konstitucii zarubezhnyh gosudarstv: Velikobritaniya, Franciya, Germaniya, Italiya, Soedinennye SHtaty Ameriki, YAponiya, Braziliya. (7-e izd.) Wolters Kluwer.

Melnyk, T.M. (2015) Zabezpechennia ekonomichnoho suverenitetu $\mathrm{V}$ umovakh vidkrytoi ekonomiky. Marketynh i menedzhment innovatsii, 1. 147-157;

Mochernyi, S. (2005). Nacional'nyi i ekonomicheskii suverenitet strany. Ekonomika Ukrainy, 10, 4-13.

Montanaro, F., Violi, F. (2020). The Remains of the Day: The International Economic Order in the Era of Disintegration. Journal of International Economic Law, 23 (2), 299322. https://doi.org/10.1093/jiel/igaa018

Nabilou, H. (2019) How to regulate bitcoin? Decentralized regulation for a decentralized cryptocurrency. International Journal of Law and Information Technology, 27 (3), 266-291. https://doi.org/10.1093/ijlit/eaz008;

Park, B.-G. (2005). Spatially selective liberalization and graduated sovereignty: Politics of neo-liberalism and "special economic zones" in South Korea. Political Geography, 24 (7), 850-873. https://doi.org/10.1016/i.polgeo.2005.06.002

Paul T., (2019) Electronic bills of lading, blockchains and smart contracts. International Journal of Law and Information Technology, 27(4), 339-371. https://doi.org/10.1093/ijlit/eaaa002

Pogge, T. (1992). Cosmopolitanism and Sovereignty. Ethics. 103 (1), 48-75. https://www.jstor.org/stable/2381495

Richardson, M. \& Stähler, F. (2019). International agreements, economic sovereignty and exit. European Economic Review, 120. https://doi.org/10.1016/j.euroecorev.2019.103 $\underline{326}$
Ruggie, J. G. (1998). Constructing the World Polity. Essays on International Institutionalization.

Schelly, C., Bessette, D., Brosemer, K., Gagnon, V., Arola, K. L., Fiss, A.,. Pearce, J. M. \& Halvorsen, K. E. (2020) Energy policy for energy sovereignty: Can policy tools enhance energy sovereignty? Solar Energy, 205, 109-112. https://doi.org/10.1016/j.solener.2020.05.056

Schmitt, C. (1979). Politische Theologie : Vier Kapitel zur Lehre von der Souveranitat (3-rd ed.). Duncker \& Humblo.

Shadikhodjaev, S. (2021) The WTO Agreement on Subsidies and Countervailing Measures and Unilateralism of Special Economic Zones. Journal of International Economic Law, 24 (2), 381-402. https://doi.org/10.1093/jiel/jgab013.

Shaffer, G. \& Gao, H. (2020). A New Chinese Economic Order? Journal of International Economic Law, 23 (3), 607-635, https://doi.org/10.1093/jiel/igaa013.

Shapoval, V.M. (ed.). (2018). Konstytutsiia Frantsurkoi Respubliky. Vyd. Moskalenko O.M.

Simo, R. Y. (2020) Trade in Services in the African Continental Free Trade Area: Prospects, Challenges and WTO Compatibility. Journal of International Economic Law, 23 (1), 6595. https://doi.org/10.1093/jiel/jgz031

Slaughter, A.-M. (2004). Disaggregated Sovereignty: Towards the Public Accountability of Global Government Networks. Government and Opposition, 39(2), 159-190.

Stankiewicz, W. J. (1969). The Validity of Sovereignty. N.Y.

Starynskyi, M.V. (2015). Problemy ta perspektyvy pravovoho rehuliuvannia valiutnykh vidnosyn v Ukraini. VVP «Mriia».

$\mathrm{Su}, \mathrm{X}$. (2018). Fragmented sovereignty and the geopolitics of illicit drugs in northern Burma. Political Geography, 63, 20-30. https://doi.org/10.1016/j.polgeo.2017.12.005

Tatsii, V. Ya., Petryshyn, O. V., Barabash, Yu. H. \& in. (red.) (2011). Konstytutsiia Ukrainy. Naukovo-praktychnyi komentar. Pravo.

Thompson, M. S. (2019). Still searching for (food) sovereignty: Why are radical discourses only partially mobilised in the independent Anglo-Caribbean? Geoforum, 101, 90-99. https://doi.org/10.1016/i.geoforum.2019.02.0 $\underline{28}$ 
Tilzey, M. (2017) Reintegrating economy, society, and environment for cooperative futures: Polanyi, Marx, and food sovereignty. Lournal of Rural Studies, 53, 317-334. https://doi.org/10.1016/j.jrurstud.2016.12.004

United Nations. (1974). Khartiia ekonomichnykh prav i oboviazkiv derzhav (1974).

https://zakon.rada.gov.ua/laws/show/995 07 $\underline{7 \# \text { Text }}$

United Nations. (1997). Kiotskyi protokol do Ramkovoi konventsii Orhanizatsii Obiednanykh Natsii pro zminu klimatu [Kyoto Protocol to the United Nations Framework Convention on Climate Change 1997 (Verkhovna Rada of Ukraine)]. https://zakon.rada.gov.ua/laws/show/995 80 $\underline{1 \# \text { Text }}$

Veerpalu, A., Jürgen, L., Rodrigues E. da C.S. \& Norta A. (2020). The hybrid smart contract agreement challenge to European electronic signature regulation. International Journal of Law and Information Technology, 28 (1), 39-84. https://doi.org/10.1093/ijlit/eaaa005.

Verkhovna Rada Ukrayiny. (1991-a). Akt proholoshennia nezalezhnosti Ukrainy [Act of Independence of Ukraine 1991, https://zakon.rada.gov.ua/laws/show/1427$\underline{12 \# \text { Text }}$

Verkhovna Rada Ukrayiny. (1991-b). Deklaratsiia prav natsionalnostei Ukrainy [Declaration of the Rights of Nationalities of Ukraine].

https://zakon.rada.gov.ua/laws/show/177112\#Text
Verkhovna Rada Ukrayiny. (1996) Konstytutsiia Ukrainy (as amended 01.01.2020) https://zakon.rada.gov.ua/laws/show/254\%D 0\%BA/96- $\% \mathrm{D} 0 \% \mathrm{~B} 2 \% \mathrm{D} 1 \% 80$

Verkhovna Rada URSR. (1990-a). Deklaratsiia pro derzhavnyi suverenitet Ukrainy 0 . [Declaration of State Sovereignty of Ukraine].

https://zakon.rada.gov.ua/laws/show/55$\underline{12 \# \text { Text }}$

Verkhovna Rada URSR. (1990-b). Pro ekonomichnu samostiinist Ukrainskoi RSR. https://zakon.rada.gov.ua/laws/show/14212\#Text

Vidigal, G. (2020). A Really Big Button That Doesn't Do Anything? The Anti-NME Clause in US Trade Agreements Between Law and Geoeconomics. Journal of International Economic Law, 23 (1), 45-64, https://doi.org/10.1093/jiel/igaa001

Walther, H. G. (1976). Imperiales Koenigtum, Konzilianismus und Volkssouveraenitaet. Mfonchen.

Witte, D. B. (1998). Sovereignty and European Integration. The Weight of Legal Tradition. In A.-M. Slaughter, A. S. Sweet \& Joseph H.H. Weiler (Eds.), The European Court and National Courts: Doctrine and Jurisprudence ( $\mathrm{p}$. 282). Bloomsbury.

Zetzsche, D., Annunziata, F., Arner, D. \& Buckley R. (2021) The Markets in CryptoAssets regulation (MiCA) and the EU digital finance strategy. Capital Markets Law Journal, 16 (2), 203-225. https://doi.org/10.1093/cmli/kmab005 